\title{
Experimental determination of stable carbon and nitrogen isotope fractionation between mangrove leaves and crabs
}

\author{
Carolin M. Herbon, Inga Nordhaus* \\ Leibniz Center for Tropical Marine Ecology (ZMT), Fahrenheitstraße 6, 28359 Bremen, Germany
}

\begin{abstract}
The analysis of benthic food webs in mangrove forests is complicated by the lack of experimental investigations of consumer-diet discrimination factors $\left(\Delta^{15} \mathrm{~N}\right.$ and $\left.\Delta^{13} \mathrm{C}\right)$ for most mangrove invertebrates. This study aimed to determine the fractionation of $\delta^{13} \mathrm{C}$ and $\delta^{15} \mathrm{~N}$ between mangrove leaves and Episesarma singaporense and E. versicolor (Sesarmidae) for $90 \mathrm{~d}$ in Java, Indonesia. The consumption rates of both species and stable isotope fractionation of leaves from 5 plant species (Acanthus ilicifolius, Aegiceras corniculatum, Avicennia alba, Derris trifoliata, Rhizophora apiculata) were compared. $\Delta^{15} \mathrm{~N}$ between $R$. apiculata leaves and muscle tissue was $5.0 \%$ for E. singaporense and $5.4 \%$ for E. versicolor after $50 \mathrm{~d}$. $\delta^{15} \mathrm{~N}$ of muscle tissue increased significantly after $50 \mathrm{~d}$, most likely due to the internal recycling of nitrogen. $\delta^{13} \mathrm{C}$ did not change during the experiment, and $\Delta^{13} \mathrm{C}$ was $5.1 \%$ for E. singaporense and $4.1 \%$ for $E$. versicolor after $90 \mathrm{~d}$. Leaves of $D$. trifoliata and $R$. apiculata were preferentially consumed, indicating their higher nutritive value. We concluded that (1) the discrimination values for mangrove crabs feeding on a leaf diet are much higher than previously assumed, which can most likely be explained by the selective assimilation of isotopic heavy carbon compounds and by metabolic cycling of non-essential amino acids; (2) the frequently used average discrimination factors are inappropriate for the study of benthic food webs in mangrove forests with a high biomass of leaf-eating crabs; and (3) $E$. singaporense and E. versicolor can meet their nitrogen demand by assimilating nitrogen from $R$. apiculata leaves and by using internal reserves for at least $50 \mathrm{~d}$.
\end{abstract}

KEY WORDS: Fractionation - Discrimination factor - Stable isotopes - Nitrogen - Carbon · Consumption rate $\cdot$ Food preference $\cdot$ Mangrove

Resale or republication not permitted without written consent of the publisher

\section{INTRODUCTION}

Food webs of mangrove forests have been investigated by stable carbon and nitrogen isotope analyses in various countries (e.g. Rodelli et al. 1984, Bouillon et al. 2004, Mazumder \& Saintilan 2009). The carbon isotopic composition $\left(\delta^{13} \mathrm{C}\right)$ changes by ca. $0.8 \%$ on average from diet to consumer, whereas the heavy ${ }^{15} \mathrm{~N}$ isotope fraction is accumulated in consumers and therefore increases with each trophic level by ca. 2.3 to $3.4 \%$ on average (Vander Zanden \& Rasmussen 2001, McCutchan et al. 2003, Caut et al. 2009). How- ever, studies have shown high variability for the consumer-diet discrimination factors $\Delta \Delta^{13} \mathrm{C}$ and $\Delta \Delta^{15} \mathrm{~N}$ with regard to specific tissues, taxonomic classes, habitat, diet isotopic ratios, protein quality of the diet, life-history level and other factors (e.g. Caut et al. 2009, Robbins et al. 2010, Boecklen et al. 2011, Florin et al. 2011). This indicates the importance of a careful choice of discrimination factors in food web studies. Although isotope discrimination factors have been examined for a range of invertebrate species, mainly insects (see Caut et al. 2009 and references therein), studies for brachyuran crabs are rare (Fantle et al. 
1999, Dittel et al. 2000, Møller et al. 2008). A metaanalysis revealed that less than $2 \%$ of all studies on isotopic determination included direct experimentation. Thus, it seems clear that further studies are needed to improve isotope mixing models, their parameters and assumptions (Boecklen et al. 2011).

Isotopic fractionation occurs primarily during anabolic processes and the production of new tissues (Yokoyama et al. 2005). The excretion of isotopically light ammonium is one of the outcomes of isotopic fractionation of nitrogen in animal tissue (Minagawa \& Wada 1984, Checkley \& Miller 1989). Amine groups containing isotopically light nitrogen such as glutamate are favored during transamination and deamination, which results in the excretion of ${ }^{14} \mathrm{~N}$ enriched proteins (Gannes et al. 1998).

The assimilation of dietary nitrogen needed for the growth of animals is increased when growth is slow and they are long-living (Nordhaus \& Wolff 2007, Linton \& Greenaway 2007). Larger consumers have longer turnover rates, so that their diet is reflected in isotopic compositions of their muscle tissue over a long time period (Post 2002). Therefore, in this study, muscle tissue was used for tracing the long-term storage of carbon and nitrogen and the stable isotope fractionation.

For Sesarmidae the largest sink for the assimilated energy of leaves is probably respiration; a small part is lost by urine or exuviae, leaving the balance for somatic production and reproduction (Emmerson \& McGwynne 1992). In general, ${ }^{13} \mathrm{C}$ and ${ }^{15} \mathrm{~N}$ in the excretion products, together with that which is assimilated, equals the amount that is consumed. A consumer's nitrogen is typically depleted of ${ }^{15} \mathrm{~N}$ in the feces compared to the tissue (DeNiro \& Epstein 1981, Checkley \& Miller 1989). Heat and water stress can lead to an increased urea concentration and amount excreted, which is probably what leads to an increase in the difference in ${ }^{15} \mathrm{~N}$ between the consumer's tissue and its diet (Ambrose 1991, 2000, Ambrose \& DeNiro 1986, Hobson 1993). Crabs also have the ability to store excess nitrogen as urate, which they keep as a nitrogen reserve (Wolcott \& Wolcott 1984, 1987, Linton \& Greenaway 1997). Large isotopic differences between a consumer and a low-nitrogen diet can result from internal recycling of nitrogen, which is also characteristic of starving animals (Hobson 1993, McCutchan et al. 2003).

In mangrove forests, many crab species primarily feed on mangrove leaf litter (e.g. Emmerson \& McGwynne 1992, Kristensen et al. 2010, Nordhaus et al. 2011). The diet of sesarmid crabs often consists of a heterogeneous mixture of mangrove litter, detrital organic compounds in sediments, encrusting algae from mangrove roots and trunks as well as invertebrates (Linton \& Greenaway 2007). Ingestion of the leaf litter also includes the microorganisms coating it, which are potentially of higher nutritional value and easier to digest than the leaves only (Linton \& Greenaway 2007).

The most abundant crab species in the Segara Anakan Lagoon (SAL) in Java, Indonesia, belong to the families Sesarmidae (Perisesarma darwinense, $P$. longicristatum, P. semperi, Episesarma singaporense, E. versicolor, E. palawense), Grapsidae (Metopograpsus latifrons) and Varunidae (Metaplax elegans) (Geist et al. 2012). The main carbon sources of the genera Episesarma and Persisesarma in the SAL are detritus, mangrove leaves and bark (Nordhaus et al. 2011). E. versicolor additionally supplements its diet with a small amount of animal material such as polychaetes. E. singaporense, on the other hand, rarely feeds on animal material. Even though these 2 species are of the same genus, they show different feeding habits in the field (C. M. Herbon unpubl. data).

In the Indo-Pacific region, several sesarmid crabs prefer decomposed leaves over mature, senescent leaves, and it was assumed that this is caused by the lower tannin and higher water content of the former (Micheli 1993, Chen \& Ye 2008). However, preferences for specific leaves differ between sesarmid crab species (Micheli 1993, Ashton 2002, Ya et al. 2008). In earlier feeding experiments with Episesarma singaporense and Perisesarma spp. in the SAL, consumption rates were highest for brown leaves of Rhizophora apiculata and Sonneratia caseolaris (Nordhaus et al. 2011). Leaves of $R$. apiculata from the sediment surface contributed to a large part of the stomach content and are therefore used in the long-term feeding experiment of this study.

We conducted experiments to determine the fractionation of carbon and nitrogen stable isotopes of mangrove leaves by sesarmid crabs. Long-term experiments were conducted with Episesarma spp. and brown Rhizophora apiculata leaves, their preferred food source, to verify the usually assumed $\Delta^{13} \mathrm{C}$ and $\Delta^{15} \mathrm{~N}$ values between consumers and their diets on which mangrove food web studies are based. To our knowledge, this is the first study examining the change in carbon and nitrogen isotopic composition in muscle tissue of sesarmid crabs over a time period of $3 \mathrm{mo}$. In addition, the consumption rates for leaves of 5 different mangrove species were determined for Episesarma singaporense, E. versicolor and Perisesarma darwinense. 
We hypothesized the following: (1) Episesarma singaporense and E. versicolor will show a response in the isotopic composition $\left(\delta^{15} \mathrm{~N}, \delta^{13} \mathrm{C}\right)$ of their muscle tissue within 3 mo when given a one-choice Rhizophora apiculata diet; (2) leaves of different mangrove tree species are consumed and fractionated differently by E. singaporense, E. versicolor and Perisesarma darwinense; (3) $\delta^{15} \mathrm{~N}$ and $\delta^{13} \mathrm{C}$ differ substantially between tissues; and (4) ovigerous females have lower $\delta^{15} \mathrm{~N}$ and $\delta^{13} \mathrm{C}$ values in their muscle tissue than non-ovigerous females because the former invest more carbon and nitrogen into the development of their eggs, leaving less for their own metabolism.

\section{MATERIALS AND METHODS}

\section{Study site}

The SAL $\left(108^{\circ} 50^{\prime}\right.$ to $109^{\circ} 00^{\prime} \mathrm{E}, 07^{\circ} 39^{\prime}$ to $\left.07^{\circ} 43^{\prime} \mathrm{S}\right)$ is a large (1002 ha), brackish water ecosystem at the southern coast of Java and is surrounded by 9238 ha of mangrove forest (Ardli \& Wolff 2009). The lagoon is separated from the Indian Ocean by the rocky, mountainous island of Nusa Kambangan. Two entrances to the lagoon, east and west of the island, allow an exchange with saline water masses. The hydrology of the SAL is governed by semidiurnal tides, ranging between $0.3 \mathrm{~m}$ at neap tides and $1.9 \mathrm{~m}$ at spring tides (Holtermann et al. 2009). Fresh water is mainly provided by the Citanduy River, the fifth largest river of Java, and the Cibereum River in the west (Holtermann et al. 2009). Sediment input through these rivers, mainly due to deforestation in the hinterland, continues to reduce the water volume of the lagoon (Ardli 2007).

Dominant benthic crabs in the intertidal region are from the genera Episesarma, Ilyoplax, Perisesarma, Macrophthalmus, Metaplax, Uca (Geist et al. 2012) and Scylla (Sastranegara et al. 2003). In the eastern lagoon, dominant tree species are Aegiceras corniculatum, Nypa fructicans and Rhizophora apiculata, the latter 2 being indicators for a mature forest. In the central lagoon, the pioneer species Avicennia alba, Aegiceras corniculatum and Sonneratia caseolaris dominate the vegetation (Hinrichs et al. 2009).

Crabs used in the laboratory experiments were collected at 2 mangrove stations. Stn 40 (naming in line with the numbers allocated in the German-Indonesian project SPICE [Science for the Protection of Indonesian Coastal Marine Ecosystems]), in a north- ern creek of the eastern lagoon $\left(108^{\circ} 59.57^{\prime} \mathrm{E}\right.$, $07^{\circ} 40.28^{\prime} \mathrm{S}$ ), is diagonally opposite of a large oil refinery. Dominant mangrove tree species are Aegiceras corniculatum, Rhizophora apiculata and Ceriops tagal (Hinrichs et al. 2009).

Stn 49 , in the central lagoon $\left(108^{\circ} 50.76^{\prime} \mathrm{E}, 07^{\circ}\right.$ $\left.41.44^{\prime} \mathrm{S}\right)$, is characterized by a low density of Xylocarpus moluccensis and Sonneratia caseolaris trees. More than $60 \%$ of the ground is covered by the understory plants Derris trifoliata and Acanthus spp. (Hinrichs et al. 2009). Stn 49 is located between the villages of Klaces and Motehan.

\section{Long-term experiment}

The change in $\delta^{15} \mathrm{~N}$ and $\delta^{13} \mathrm{C}$ in the muscle tissue of 2 crab species fed on a Rhizophora apiculata diet was investigated over $90 \mathrm{~d}$. When possible, up to 25 adult individuals each of Episesarma singaporense and E. versicolor of about $4 \mathrm{~cm}$ carapace width were collected at Stns 40 and 49 in July 2009 and kept separately in glass aquaria $(40 \times 40 \times 40 \mathrm{~cm})$ in 21 of lagoon water (water depth about $2 \mathrm{~cm}$ ). A blue-colored tumbler allowed the crabs to hide, and a saucer placed upside down allowed the crabs to move out of the water. Sufficient brown $R$. apiculata leaves were placed on top of the saucer, as previous studies showed an abundance of this leaf in the stomach contents (Nordhaus et al. 2011). Senescent leaves were handpicked at Stns 40 and 49 from the sediment surface. Aquaria were cleaned every 4th day, and water was exchanged with fresh lagoon water. The leaves from both stations were measured regularly for isotopic compositions, with 3 replicates at the beginning $\left(T_{0}\right)$, middle $\left(T_{44}\right)$ and end $\left(T_{90}\right)$ of the experiment. The reference value is the average of all measurements, as values did not change significantly either over time or between stations $\left(\delta^{15} \mathrm{~N}: 2.35 \pm 0.63, \delta^{13} \mathrm{C}\right.$ : $-28.76 \pm 1.12$ ).

Over a period of 90 d, 4 to 5 individuals of Episesarma singaporense from each station were taken from the aquaria at 5 sampling times $\left(T_{0}, T_{20 / 30}, T_{50}\right.$, $\left.T_{70}, T_{90}\right)$. Crabs were frozen for about $24 \mathrm{~h}$ and dissected to remove muscle tissue from the chelae and legs. For E. versicolor, the same procedure was conducted for animals from Stn 40, but only 3 individuals could be used per sampling time because of time limitations and the difficulty of catching them in the field. For the same reason, only a limited number of individuals of $E$. versicolor were caught at Stn 49 , which led to a setup of only 2 sampling 
times $\left(T_{0}, T_{90}\right)$ with 3 animals each. Individuals were not collected at additional stations, as each station differs in food availability and quality and therefore provides different starting conditions for the experiment.

Muscle tissues were dried in the oven at $40^{\circ} \mathrm{C}$ and ground afterwards to homogenize the sample. Samples were stored at $-20^{\circ} \mathrm{C}$ until analysis (see 'Sample analyses' section).

\section{Consumption rate experiment}

Six adult individuals each of Episesarma singaporense and E. versicolor of about $4 \mathrm{~cm}$ carapace width were collected at Stn 40 in August 2009. They were kept separately in glass aquaria with lagoon water ( $2 \mathrm{~cm}$ depth) with objects to hide in and climb on. Before the first experiment was run, crabs were kept without food for $4 \mathrm{~d}$ to allow them to empty their gut. Crabs were also deprived of food for $4 \mathrm{~d}$ between each experiment. The aquaria were cleaned, and the water was exchanged after each experiment to avoid buildup of toxic ammonium concentrations in the water through excretion.

Five $24 \mathrm{~h}$ experiments were conducted. During each experiment, leaves of only 1 of the 5 plant species were provided to all crabs. Leaves were provided in the following order: Rhizophora apiculata, Acanthus ilicifolius, Derris trifoliata, Avicennia alba and Aegiceras corniculatum (Table 1). These are the most dominant species in the SAL (Hinrichs et al. 2009). The same crab individuals were used for each consumption experiment, as it was not possible to provide new crabs for each experiment because of logistical restrictions.

Brown leaves were handpicked from the sediment surface at Stns 40 and 49. Within each experiment, each crab was supplied with about $3 \mathrm{~g}$ of leaves at the start. The exact weight of leaves provided was noted. When this food became scarce, more weighed leaves were provided. Feces were removed every hour throughout the experiment to limit leaching of carbon and nitrogen.

Wet weight of remaining leaves and produced feces within the $24 \mathrm{~h}$ of the experiment were determined. Consumption rates were calculated from the difference between leaf mass given and leaf mass remaining and were correlated to crab wet weight. As leaves soak up moisture within the $24 \mathrm{~h}$ of the experiment, a correction value was needed for the leaves. The weights of the provided leaves were corrected with a factor experimentally determined by the difference in the weight of whole leaves before and after incubation in lagoon water for $24 \mathrm{~h}$. For each species, 5 leaves were incubated to determine a correction value, which was calculated as follows: correction value $(\%)=100 /($ leaf mass before incubation) $\times$ [(leaf mass before incubation) - (leaf mass after incubation)]. The correction values were $100 \%$ for Rhizophora apiculata (meaning that $R$. apiculata soaked up moisture during the $24 \mathrm{~h}$ of incubation equivalent to $100 \%$ of its starting weight), $58 \%$ for Acanthus, $43 \%$ for Derris, $29 \%$ for Avicennia alba and $94 \%$ for Aegiceras corniculatum.

The consumption rate experiment was also conducted on Perisesarma darwinense. As these crabs do not survive alone in an aquarium, they were organized into groups of 3. To calculate consumption rates, values were divided by 3 , as the crabs had similar body sizes.

\section{Comparison of tissues}

Five individuals of 8 decapod species (Episesarma singaporense, E. versicolor, Epixanthus dentaus, Perisesarma darwinense, P. semperi, Metaplax elegans, Scylla serrata, Uca forcipata) were collected in August 2008 by hand and frozen for $24 \mathrm{~h}$. These species were chosen because they are abundant in the lagoon and include facultative leaf-feeders (Episesarma, Perisesarma), detritus feeders (Metaplax) and carnivores (Epixanthus, Scylla). After defrosting, the crabs were dissected and muscle tissue, hepatopancreas and stomach contents (if available) were removed. Samples were dried in an oven at $40^{\circ} \mathrm{C}$, ground to homogenize the samples and stored at $-20^{\circ} \mathrm{C}$ until analysis (see 'Sample analyses' section).

Table 1. \% $, \% \mathrm{~N}, \mathrm{C} / \mathrm{N}$ and carbon and nitrogen isotopic compositions of leaves in the order offered in the consumption rate experiments; data are mean $\pm \mathrm{SD}$

\begin{tabular}{|lccccc|}
\hline Species & $\% \mathrm{C}$ & $\% \mathrm{~N}$ & $\mathrm{C} / \mathrm{N}$ & $\delta^{13} \mathrm{C}(\%)$ & $\delta^{15} \mathrm{~N}(\%)$ \\
\hline Rhizophora apiculata & $44.4 \pm 1.4$ & $0.6 \pm 0.2$ & $83.7 \pm 21.1$ & $-27.6 \pm 0.3$ & $2.6 \pm 0.5$ \\
Acanthus ilicifolius & $39.5 \pm 1.4$ & $1.0 \pm 0.1$ & $39.8 \pm 4.2$ & $-28.5 \pm 1.3$ & $3.3 \pm 0.6$ \\
Derris trifoliata & $37.8 \pm 5.1$ & $0.9 \pm 0.1$ & $42.5 \pm 5.2$ & $-26.9 \pm 0.6$ & $0.6 \pm 0.5$ \\
Avicennia alba & $42.0 \pm 1.0$ & $0.7 \pm 0.2$ & $58.8 \pm 16.0$ & $-27.5 \pm 0.7$ & $4.6 \pm 1.7$ \\
Aegiceras corniculatum & $49.0 \pm 1.0$ & $0.7 \pm 0.3$ & $76.6 \pm 29.4$ & $-29.5 \pm 0.5$ & $4.2 \pm 0.3$ \\
\hline
\end{tabular}




\section{Comparison of ovigerous and non-ovigerous females}

To compare $\delta^{13} \mathrm{C}$ and $\delta^{15} \mathrm{~N}$ in the muscle tissues of ovigerous and non-ovigerous females, 2 to 5 individuals each of Episesarma versicolor and E. singaporense were collected in July 2009 at Stn 40 . The animals were frozen for $24 \mathrm{~h}$, and muscle tissue was dissected from the chelae after defrosting. Tissues were dried at $40^{\circ} \mathrm{C}$ in an oven, ground afterwards and stored at $-20^{\circ} \mathrm{C}$ until analysis (see 'Sample analyses' section).

\section{Sample analyses}

Samples were combusted in the Carlo Erba NA 2100 elemental analyzer for measurement of total (= organic) carbon and total nitrogen content without previous $\mathrm{HCl}$ treatment, as previous tests showed no significant differences between samples treated with or without $\mathrm{HCl}$. Apple leaf standard was used as a reference. Stable isotope ratios were determined separately using a coupled elemental analyzer-gas isotope ratio mass spectrometer (ConFlo III) and expressed relative to conventional standards $\delta R=$ $\left[\left(X_{\text {sample }} / X_{\text {standard }}\right)-1\right] \times 1000 \%$, where $R={ }^{13} \mathrm{C}$ or ${ }^{15} \mathrm{~N}$ and $X={ }^{13} \mathrm{C} /{ }^{12} \mathrm{C}$ or ${ }^{15} \mathrm{~N} /{ }^{14} \mathrm{~N}$. Ammonium sulfate (IAEA-N1, IAEA-N2) was used as the standard for $\delta^{15} \mathrm{~N}$, and graphite (USGS-24) and mineral oil (NBS22) were used as the standards for $\delta^{13} \mathrm{C}$. Analytical precision was $\pm 0.2 \%$ o for both nitrogen and carbon, as estimated from standards analyzed together with the samples.

\section{Statistics}

Significant differences over time in the long-term experiment were calculated separately for each crab species and station with Statistica $^{\circledR}$ using ANOVA followed by a Tukey's post hoc test for parametric data and a Kruskal-Wallis-ANOVA (K-W-ANOVA) followed by Mann-Whitney $U$-test (with Bonferroni correction) for nonparametric data. Data that were not normally distributed (Shapiro-Wilk's test) were log-transformed to achieve normality. Data were tested for homogeneity of variances (Levene's test), and parametrical proceedings were conducted for homogeneous data only.

To find significant differences between tissues, an ANOVA followed by a Tukey's post hoc test was used, as data were normally distributed and homogeneous. To analyze the difference between ovigerous and non-ovigerous females and between consumption rates for different plant species, the same statistical analyses (ANOVA, Tukey's post hoc test) were applied.

\section{RESULTS}

\section{Long-term experiment}

Nitrogen isotopic composition reflected a response to the Rhizophora apiculata diet after 50 to $70 \mathrm{~d}$ (Fig. 1). A significant increase in $\delta^{15} \mathrm{~N}$ was recorded between $T_{50}$ and $T_{70}$ and between $T_{70}$ and $T_{90}$ for Episesarma singaporense from Stn 49 (ANOVA: $\mathrm{p}<$ 0.001, Tukey's HSD test: $\mathrm{p}<0.05)$ and between $T_{70}$ and $T_{90}$ from Stn 40 (K-W-ANOVA: p < 0.05, MannWhitney $U$-test: $\mathrm{p}<0.05)$. For E. versicolor, significant differences were found between $T_{70}$ and $T_{90}$ at Stn 40 (ANOVA: $\mathrm{p}<0.05$, T-HSD test: $\mathrm{p}<0.05$ ), whereas $\delta^{15} \mathrm{~N}$ was similar at $T_{0}$ and $T_{90}$ for animals from Stn 49 (ANOVA: $\mathrm{p}<0.05$, T- HSD test: $\mathrm{p}>0.05$ ). The increase in $\delta^{15} \mathrm{~N}$ between leaves and muscle tissue was much higher for crabs from Stn 40 than for those from Stn 49 (Table 2).

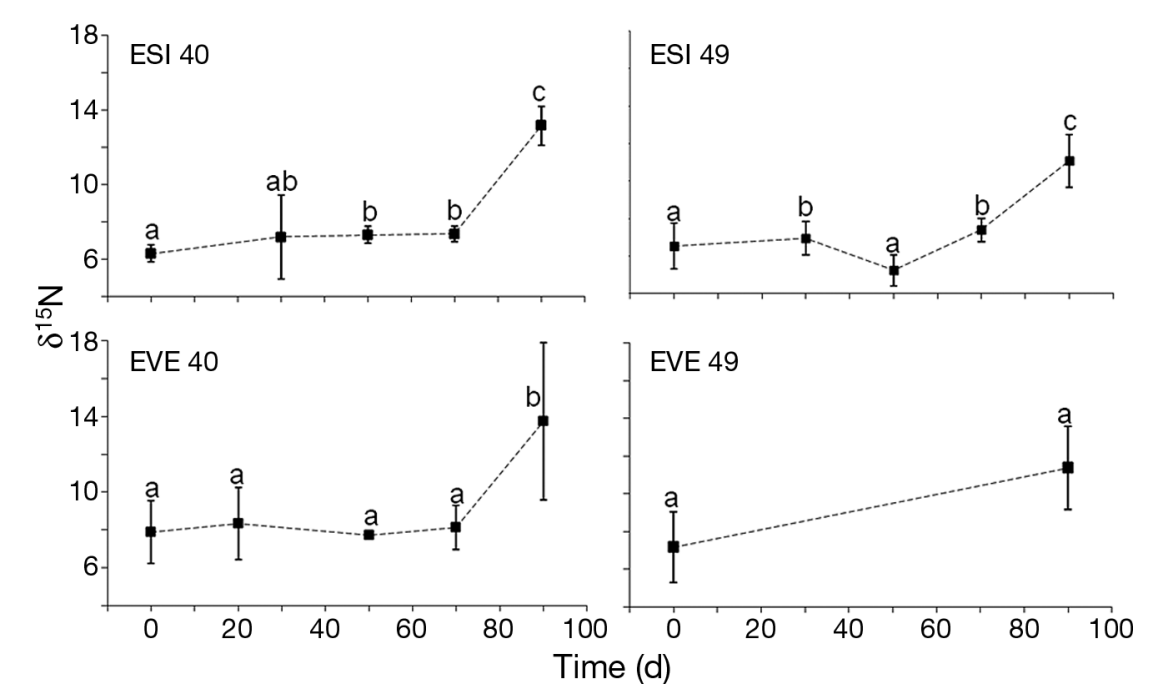

Fig. 1. Change in nitrogen isotopic composition $\left(\delta^{15} \mathrm{~N}\right)$ of muscle tissue over time in Episesarma singaporense (ESI) and E. versicolor (EVE) from Stns 40 and 49 fed on Rhizophora apiculata leaves $\left(\delta^{15} \mathrm{~N}=2.4 \%\right.$ ). $\mathrm{n}=3$ to 5 crabs each; data are mean \pm SD. Different letters over bars indicate significant differences between sampling times (same letter = not significantly different) 
Table 2. Episesarma singaporense and E. versicolor. Differences in isotopic composition $\left(\Delta^{13} \mathrm{C}, \Delta \Delta^{15} \mathrm{~N} ; \%\right)$ between leaves and muscle tissue in the beginning $\left(T_{0}\right)$, after $50 \mathrm{~d}$ $\left(T_{50}\right)$ and at the end $\left(T_{90}\right)$ of the experiment for crabs taken from 2 stations $(40,49)$. Dashes indicate no measurement due to insufficient number of individuals

\begin{tabular}{|cccccc|}
\hline & Species & Station & $T_{0}$ & $T_{50}$ & $T_{90}$ \\
\hline$\Delta^{13} \mathrm{C}$ & E. singaporense & 40 & 4.03 & 4.73 & 5.08 \\
& & 49 & 5.73 & 5.85 & 5.31 \\
& E. versicolor & 40 & 3.88 & 4.13 & 4.08 \\
$\Delta^{15} \mathrm{~N}$ & E. singaporense & 49 & 4.59 & - & 5.91 \\
& & 49 & 4.96 & 4.96 & 10.81 \\
& E. versicolor & 40 & 5.53 & 5.38 & 8.73 \\
& & 49 & 4.80 & - & 9.01 \\
\hline
\end{tabular}

Carbon isotopic compositions remained the same over the whole duration of the experiment (K-WANOVA and ANOVA: $\mathrm{p}>0.05)$ except for Episesarma singaporense (Stn 40) between the first 2 samplings (ANOVA: $\mathrm{p}<0.01$, T-HSD test: $\mathrm{p}<0.01$, Fig. 2). There was no approximation of isotopic composition values of the crab muscle tissue to those of the Rhizophora apiculata leaves (Table 1).

Differences in carbon and nitrogen isotopic compositions between the muscle tissue and leaves were significant at $T_{0}, T_{50}$ and $T_{90}$ for both crab species at both stations (t-tests: $\mathrm{p}<0.01$ each). The $\delta^{15} \mathrm{~N}$ value of crab tissue differed significantly between stations at $T_{90}$ for Episesarma singaporense, and $\delta^{13} \mathrm{C}$ differed significantly between stations at $T_{0}(t$-tests: $\mathrm{p}<0.001$ each). In the case of $E$. versicolor, $\delta^{15} \mathrm{~N}$ was similar at both stations, whereas $\delta^{13} \mathrm{C}$ differed significantly between stations at $T_{90}(t$-test: $\mathrm{p}<0.05)$.

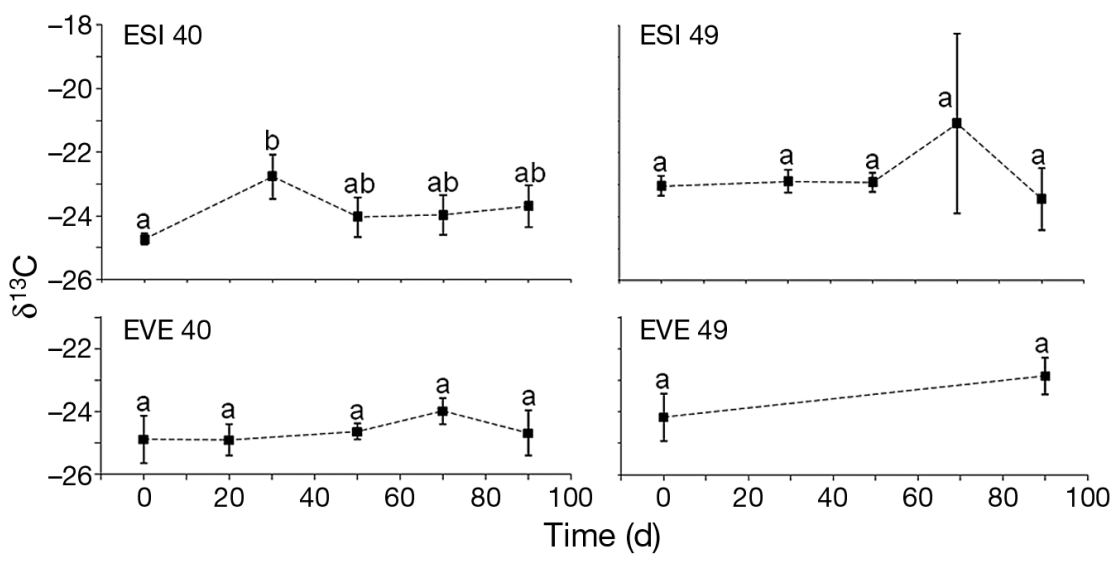

Fig. 2. Change in carbon isotopic composition $\left(\delta^{13} \mathrm{C}\right)$ of muscle tissue over time in Episesarma singaporense (ESI) and E. versicolor (EVE) from Stns 40 and 49 fed on Rhizophora apiculata leaves $\left(\delta^{13} \mathrm{C}=-28.8 \%\right.$ ). $\mathrm{n}=3$ to $5 \mathrm{crabs}$ each; data shown are averages with standard deviation. Different letters over bars indicate significant differences between sampling times (same letter $=$ not significantly different)

\section{Consumption rates and isotopic fractionation in relation to plant species}

Episesarma preferred leaves of Rhizophora apiculata (E. versicolor: $127.3 \pm 63.9 ;$ E. singaporense: $157.4 \pm 110.3$; in mg leaf $\mathrm{g}^{-1}$ crab wet wt d ${ }^{-1}$; Fig. 3) and Derris trifoliata (E. versicolor: $81.8 \pm 29.1 \mathrm{mg} ; E$. singaporense: $128.2 \pm 53.8 \mathrm{mg}$ ). Leaves of Acanthus ilicifolius and Aegiceras corniculatum were only consumed in small amounts (Fig. 3). Perisesarma darwinense only consumed $D$. trifoliata (124.9 mg).

Nitrogen content $(\% \mathrm{~N})$ did not change significantly between leaves offered and feces and was highest for Acanthus ilicifolius in both crab species (Fig. 4). Average differences in carbon $(\% \mathrm{C})$ between leaves and feces were lowest for A. ilicifolius and highest for Aegiceras corniculatum and Rhizophora apiculata (Fig. 4). On average, 2 fecal pellets $\mathrm{h}^{-1}$ were produced and were mainly found under the crabs' bodies or on the remaining leaves.

The differences in both $\delta^{13} \mathrm{C}$ and $\delta^{15} \mathrm{~N}$ between leaves and feces are negative if the heavy isotope $\left({ }^{13} \mathrm{C},{ }^{15} \mathrm{~N}\right)$ is enriched in feces; positive values result from the opposite. The difference in carbon isotopic composition between leaves and feces (Fig. 4) was not significantly different between the different leaves offered (K-W-ANOVA: $\mathrm{p}>0.05$ for both crab species). In the case of $\Delta^{15} \mathrm{~N}$, significantly higher values were recorded for crabs feeding on leaves of Aegiceras corniculatum (K-W-ANOVA: $\mathrm{p}<0.05$ for Episesarma versicolor, Mann-Whitney $U$-test: $\mathrm{p}<0.05$ for E. singaporense) (Fig. 4). It has to be considered that standard deviations are particularly high for $\Delta^{15} \mathrm{~N}$.

There was no correlation between the difference in $\% \mathrm{C}$ and $\delta^{13} \mathrm{C}$ as well as the difference in $\% \mathrm{~N}$ and $\delta^{15} \mathrm{~N}$ and $\delta^{15} \mathrm{~N}$ between the leaves of all 5 plant species and the respective feces of the 2 crab species.

\section{Comparison of tissues}

Muscle tissue had significantly higher $\delta^{13} \mathrm{C}$ values than hepatopancreas tissue (see Table 3), except for Perisesarma darwinense and Scylla serrata, whose $\delta^{13} \mathrm{C}$ values were similar in all tissues. $\delta^{15} \mathrm{~N}$ was significantly higher in muscle tissue than in hepatopancreas tissue of Episesarma versicolor and S. serrata (Table 3). 


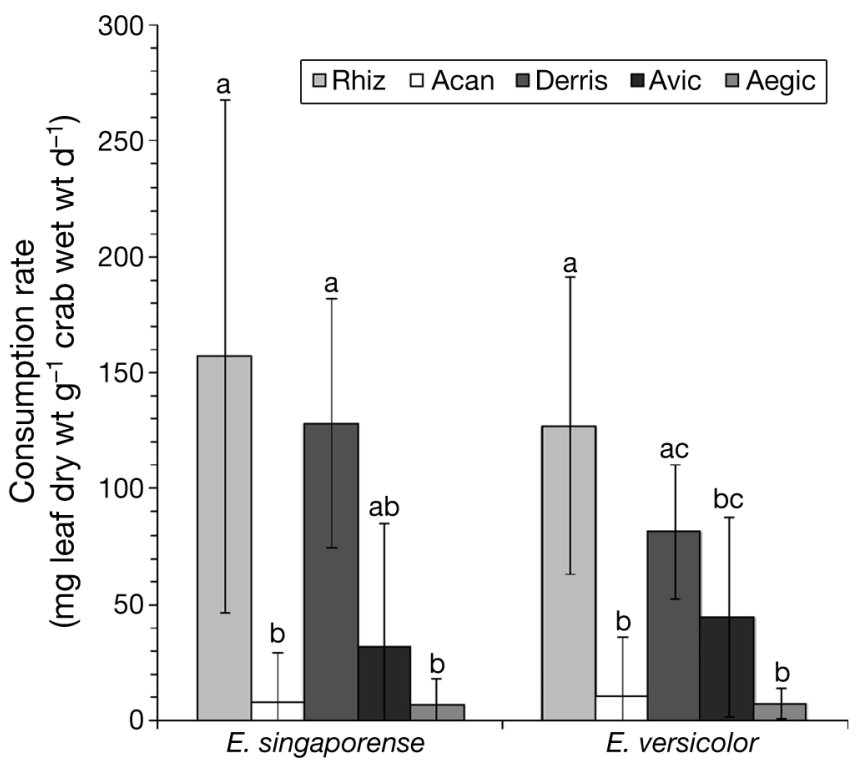

Fig. 3. Episesarma singaporense and E. versicolor. Consumption rates (mean $\pm \mathrm{SD}$ ) of crabs ( $\mathrm{n}=6$ for each species) fed with 5 mangrove and shrub species (in order offered: Rhizophora apiculata [Rhiz], Acanthus ilicifolius [Acan], Derris trifoliata [Derris], Avicennia alba [Avic] and Aegiceras corniculatum [Aegic]). Letters over bars indicate significant differences between sampling times (same letter $=$ not significantly different)

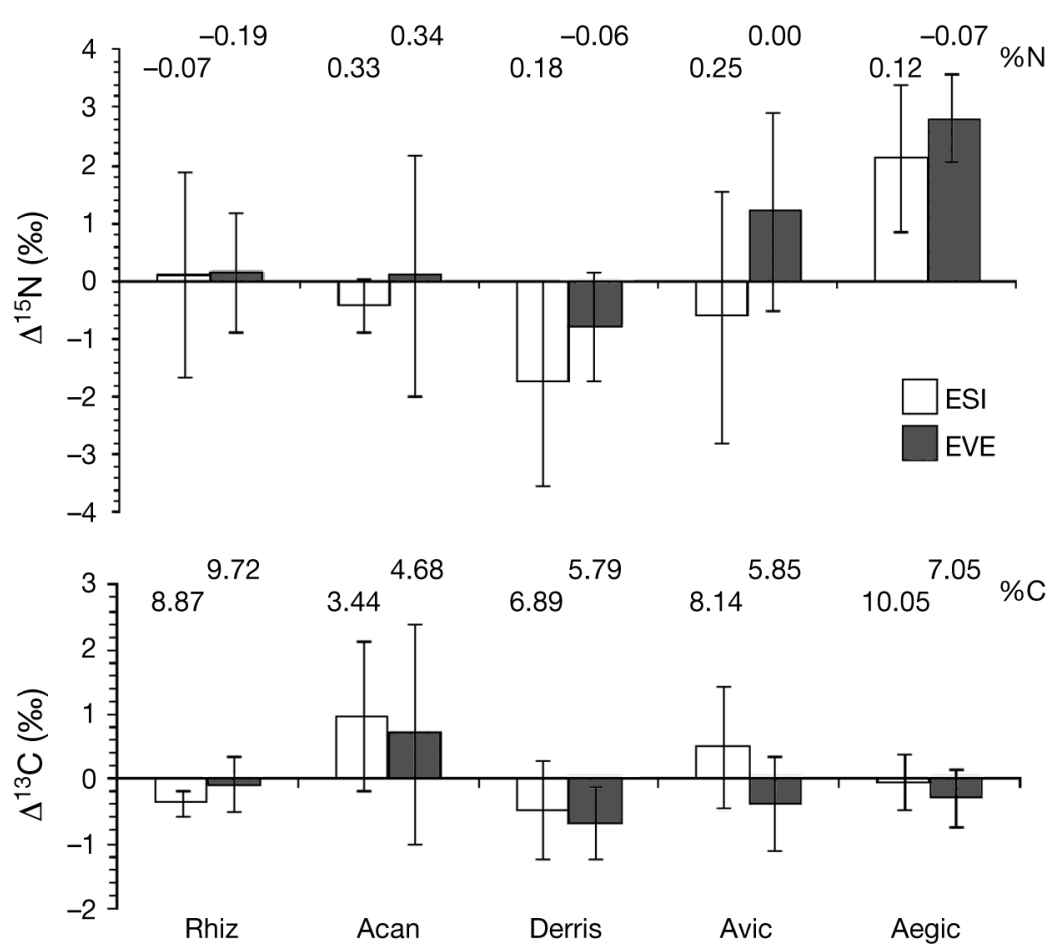

Fig. 4. Episesarma singaporense (ESI) and E. versicolor (EVI). Discrepancy of $\delta^{15} \mathrm{~N}$ and $\delta^{13} \mathrm{C}$ between leaves and feces, calculated as $\Delta X=\delta X$ of leaf $-\delta X$ of feces with $X={ }^{15} \mathrm{~N}$ and ${ }^{13} \mathrm{C}$, with standard deviation. Numbers over bars indicate mean difference in carbon $(\% \mathrm{C})$ and nitrogen $(\% \mathrm{~N})$ between eaten leaves and feces. See Fig. 3 for leaf abbreviations

\section{Comparison of ovigerous and non-ovigerous females}

$\delta^{15} \mathrm{~N}$ and $\delta^{13} \mathrm{C}$ were similar in ovigerous and nonovigerous females (ANOVA: $p>0.05$ for both species). Standard deviation was high for all treatments in $\delta^{15} \mathrm{~N}$ but only for non-ovigerous females in $\delta^{13} \mathrm{C}$ (Table 4).

\section{DISCUSSION}

\section{Long-term experiment}

During the long-term experiment, $\delta^{15} \mathrm{~N}$ strongly increased in the muscle tissue of the crabs fed on a Rhizophora apiculata leaf diet after 50 to $70 \mathrm{~d}$. Previous studies showed that animals (e.g. seabirds, caterpillars or aphids) fed on a diet with a low nitrogen content start recycling their internal nitrogen to further keep up their metabolism and excrete the isotopically light nitrogen, which leads to an increase in ${ }^{15} \mathrm{~N}$ in their tissue (Hobson 1993, Webb et al. 1998, McCutchan et al. 2003). This also occurs in starving animals (Daphnia magna), as lean body mass is lost without replacement of excreted ${ }^{14} \mathrm{~N}$ (Adams \& Sterner 2000). Urate accumulation derived from high-nitrogen diets functions as a nitrogen reserve in crustaceans (Greenaway 1991, O'Donnell \& Wright 1995, Linton \& Greenaway 1997). Our results indicate that Episesarma spp. can meet their nitrogen demand for at least $7 \mathrm{wk}$, after which a nitrogen deficiency occurred and internal nitrogen was recycled. A similar result was recorded for the crab Gecarcoidea natalis, which is able to keep the nitrogen balanced over 6 wk in the laboratory (Linton \& Greenaway 1997).

Gorokhova \& Hansson (1999) showed that the dietary $\delta^{15} \mathrm{~N}$ is mirrored in the muscle tissue of crustaceans after 6 to 8 wk. This suggests that the time frame of $70 \mathrm{~d}$ during our experiment was long enough to observe a change in the isotopic composition in the muscle tissue. However, the difference between $\delta^{15} \mathrm{~N}$ in muscles and leaves was still about $5 \%$ after 7 to $10 \mathrm{wk}$, indicating that the difference between tissue and leaves for these crabs is 
Table 3. $\% \mathrm{C}, \% \mathrm{~N}, \mathrm{C} / \mathrm{N}$ ratios and carbon and nitrogen isotopic composition (\%) in different tissues of 8 brachyuran species. Data are mean $\pm \mathrm{SD}$. Asterisks indicate significant differences between 2 tissues $\left({ }^{*} \mathrm{p}<0.05,{ }^{* *} \mathrm{p}<0.01,{ }^{* * *} \mathrm{p}<0.001\right)$

\begin{tabular}{|c|c|c|c|c|c|c|c|}
\hline Species & Parameter & $\begin{array}{l}\text { Stomach } \\
\text { content (S) }\end{array}$ & $\begin{array}{l}\text { Hepatopan- } \\
\text { creas }(\mathrm{H})\end{array}$ & $\begin{array}{l}\text { Muscle } \\
\text { (M) }\end{array}$ & $\mathrm{S} / \mathrm{H}$ & $\mathrm{H} / \mathrm{M}$ & $\mathrm{S} / \mathrm{M}$ \\
\hline \multirow[t]{3}{*}{ Episesarma singaporense } & $\% \mathrm{C}$ & $42.6 \pm 2.6$ & $44.6 \pm 8.2$ & $38.9 \pm 3.3$ & & & \\
\hline & $\% \mathrm{~N}$ & $5.6 \pm 2.5$ & $5.1 \pm 0.8$ & $7.0 \pm 2.1$ & & & \\
\hline & $\mathrm{C} / \mathrm{N}$ & $8.4 \pm 2.5$ & $9.0 \pm 2.7$ & $6.0 \pm 2.0$ & & & \\
\hline \multirow[t]{2}{*}{ ANOVA: $\mathrm{p}<0.05$} & $\delta^{13} \mathrm{C}(\%)$ & $-27.9 \pm 0.7$ & $-29.2 \pm 1.2$ & $-24.8 \pm 0.5$ & & $* * *$ & $* *$ \\
\hline & $\delta^{15} \mathrm{~N}(\%)$ & $10.7 \pm 2.1$ & $10.3 \pm 0.7$ & $11.0 \pm 2.2$ & & & \\
\hline \multirow{3}{*}{ Episesarma versicolor } & $\% \mathrm{C}$ & $39.7 \pm 2.3$ & $42.6 \pm 6.0$ & $38.1 \pm 5.2$ & & & \\
\hline & $\% \mathrm{~N}$ & $4.6 \pm 0.3$ & $6.2 \pm 0.7$ & $7.6 \pm 1.1$ & & & ** \\
\hline & $\mathrm{C} / \mathrm{N}$ & $8.6 \pm 0.7$ & $6.9 \pm 1.3$ & $5.0 \pm 0.3$ & & * & ** \\
\hline \multirow[t]{2}{*}{ ANOVA: $\mathrm{p}<0.01$} & $\delta^{13} \mathrm{C}(\%)$ & $-27.6 \pm 0.6$ & $-27.9 \pm 1.1$ & $-24.9 \pm 0.5$ & & $* *$ & $* *$ \\
\hline & $\delta^{15} \mathrm{~N}(\%)$ & $11.4 \pm 0.8$ & $10.6 \pm 1.9$ & $17.4 \pm 3.0$ & & $* *$ & ${ }^{*}$ \\
\hline \multirow[t]{3}{*}{ Epixanthus dentatus } & $\% \mathrm{C}$ & $41.7 \pm 5.4$ & $32.1 \pm 10.2$ & $37.9 \pm 6.3$ & & & \\
\hline & $\% \mathrm{~N}$ & $9.0 \pm 1.6$ & $4.6 \pm 0.6$ & $8.1 \pm 1.7$ & * & & \\
\hline & $\mathrm{C} / \mathrm{N}$ & $4.7 \pm 0.7$ & $6.9 \pm 1.6$ & $4.7 \pm 0.4$ & & & \\
\hline \multirow[t]{2}{*}{ ANOVA: $\mathrm{p}<0.01$} & $\delta^{13} \mathrm{C}(\%)$ & $-23.8 \pm 0.9$ & $-26.5 \pm 0.8$ & $-22.9 \pm 0.6$ & * & $* *$ & \\
\hline & $\delta^{15} \mathrm{~N}(\%)$ & $10.7 \pm 0.9$ & $12.7 \pm 0.5$ & $16.4 \pm 3.0$ & * & & \\
\hline \multirow[t]{3}{*}{ Perisesarma semperi } & $\% \mathrm{C}$ & 43.8 & $50.3 \pm 4.5$ & $40.5 \pm 2.6$ & & $* *$ & \\
\hline & $\% \mathrm{~N}$ & 13.0 & $7.6 \pm 4.9$ & $7.3 \pm 2.6$ & & & \\
\hline & $\mathrm{C} / \mathrm{N}$ & 3.4 & $11.2 \pm 10.5$ & $6.0 \pm 1.4$ & & & \\
\hline \multirow[t]{2}{*}{ ANOVA: $\mathrm{p}<0.01$} & $\delta^{13} \mathrm{C}(\%)$ & -25.7 & $-30.0 \pm 1.9$ & $-23.0 \pm 1.9$ & & $* *$ & \\
\hline & $\delta^{15} \mathrm{~N}(\%)$ & 7.1 & $9.4 \pm 0.7$ & $8.4 \pm 0.9$ & & & \\
\hline \multirow[t]{3}{*}{ Perisesarma darwinense } & $\% \mathrm{C}$ & $39.5 \pm 4.2$ & $38.3 \pm 7.5$ & $39.0 \pm 5.8$ & & & \\
\hline & $\% \mathrm{~N}$ & $3.6 \pm 0.7$ & $6.8 \pm 2.6$ & $9.3 \pm 1.9$ & & & $* *$ \\
\hline & $\mathrm{C} / \mathrm{N}$ & $11.7 \pm 4.1$ & $6.2 \pm 2.4$ & $4.4 \pm 1.6$ & * & & $* *$ \\
\hline \multirow[t]{2}{*}{ ANOVA: $\mathrm{p}>0.05$} & $\delta^{13} \mathrm{C}(\%)$ & $-27.5 \pm 1.2$ & $-26.2 \pm 3.5$ & $-24.8 \pm 1.6$ & & & \\
\hline & $\delta^{15} \mathrm{~N}(\%)$ & $9.8 \pm 0.9$ & $8.2 \pm 1.5$ & $8.5 \pm 0.9$ & & & \\
\hline \multirow[t]{3}{*}{ Uca forcipata } & $\% \mathrm{C}$ & $37.5 \pm 18.3$ & $53.0 \pm 3.6$ & $46.7 \pm 5.9$ & & & \\
\hline & $\% \mathrm{~N}$ & $2.0 \pm 0.3$ & $2.2 \pm 0.8$ & $3.1 \pm 3.2$ & & & \\
\hline & $\mathrm{C} / \mathrm{N}$ & $18.0 \pm 8.3$ & $25.9 \pm 9.3$ & $25.7 \pm 14.7$ & & & \\
\hline \multirow[t]{2}{*}{ ANOVA: $\mathrm{p}<0.05$} & $\delta^{13} \mathrm{C}(\%)$ & $-22.1 \pm 0.6$ & $-23.6 \pm 0.8$ & $-18.6 \pm 0.9$ & & $* * *$ & *** \\
\hline & $\delta^{15} \mathrm{~N}(\% \circ)$ & $10.1 \pm 1.2$ & $9.6 \pm 0.7$ & $16.0 \pm 5.7$ & & & \\
\hline \multirow[t]{3}{*}{ Metaplax elegans } & $\% \mathrm{C}$ & - & $60.1 \pm 0.6$ & $41.3 \pm 1.8$ & & $* * *$ & \\
\hline & $\% \mathrm{~N}$ & - & $4.3 \pm 0.4$ & $11.6 \pm 1.1$ & & $* * *$ & \\
\hline & $\mathrm{C} / \mathrm{N}$ & - & $14.1 \pm 1.2$ & $3.6 \pm 0.2$ & & $* * *$ & \\
\hline \multirow[t]{2}{*}{ ANOVA: $\mathrm{p}<0.001$} & $\delta^{13} \mathrm{C}(\% \circ)$ & - & $-23.7 \pm 1.0$ & $-20.5 \pm 1.8$ & & $*$ & \\
\hline & $\delta^{15} \mathrm{~N}(\%)$ & - & $10.9 \pm 0.9$ & $7.7 \pm 0.7$ & & $* *$ & \\
\hline \multirow[t]{3}{*}{ Scylla serrata } & $\% \mathrm{C}$ & - & $51.0 \pm 2.7$ & $37.3 \pm 5.0$ & & $* * *$ & \\
\hline & $\% \mathrm{~N}$ & - & $6.2 \pm 3.2$ & $4.4 \pm 2.2$ & & & \\
\hline & $\mathrm{C} / \mathrm{N}$ & - & $10.5 \pm 6.4$ & $10.1 \pm 4.1$ & & & \\
\hline \multirow[t]{2}{*}{ ANOVA: $p>0.05$} & $\delta^{13} \mathrm{C}(\%)$ & - & $-28.3 \pm 2.7$ & $-25.2 \pm 1.5$ & & & \\
\hline & $\delta^{15} \mathrm{~N}(\%)$ & - & $13.4 \pm 2.1$ & $17.1 \pm 1.9$ & & * & \\
\hline
\end{tabular}

higher than the reported average of 2.3 to $3.4 \%$ (Vander Zanden \& Rasmussen 2001, McCutchan et al. 2003, Caut et al. 2009).

However, this assumes that the crabs assimilated nitrogen from the leaf diet. In our study, all crabs molted during the experiment. Crabs molt only if they have a sufficient food supply (Hagerman 1983, Micheli 1993). The molting frequency of crabs fed on Rhizophora stylosa leaves was higher than that of crabs fed on other mangrove species (Micheli 1993), indicating the influence of food quality on molting. Although mangrove leaves have a lower nutritional quality than animal tissue in terms of nitrogen, they have a significant effect on growth and reproduction (Micheli 1993). In previous starvation experiments, Uca tangeri on average had a survival rate of 34 d (Klaassen \& Ens 1993), which leads us to the assumption that our experiment could have revealed a possible failure of assimilation or deficiency in nitrogen much earlier than what was observed after 70 d. Kwok \& Lee (1995) showed that decapod crabs can survive up to $200 \mathrm{~d}$ on a mangrove leaf diet only. Feeding experiments with the omnivorous salt marsh crab Armases 
Table 4. Episesarma versicolor and E. singaporense. Carbon and nitrogen isotopic compositions of ovigerous and nonovigerous females. Data are mean $\pm \mathrm{SD}, \mathrm{n}=$ number of individuals

\begin{tabular}{|lcccc|}
\hline Species & Ovigerous & $\delta^{15} \mathrm{~N}(\%)$ & $\delta^{13} \mathrm{C}(\%)$ & $\mathrm{n}$ \\
\hline E. versicolor & + & $6.7 \pm 1.5$ & $-22.9 \pm 0.4$ & 2 \\
\multirow{2}{*}{ E. singaporense } & + & $6.2 \pm 1.5$ & $-22.0 \pm 1.6$ & 4 \\
& - & $6.2 \pm 1.2$ & $-22.6 \pm 0.6$ & 5 \\
& - & $6.8 \pm 1.3$ & $-21.3 \pm 3.9$ & 5 \\
\hline
\end{tabular}

cinereum revealed that growth rate and the proportion of crabs molting were higher for animals feeding on invertebrate tissue; however, growth and molting also occurred on single diets of leaf litter, fresh leaves and mud (Buck et al. 2003). Also, the litter-consuming mangrove crab Ucides cordatus fed with senescent $R$. mangle leaves assimilated $79 \%$ of the leaf carbon and $45 \%$ of the leaf nitrogen (Nordhaus \& Wolff 2007). In addition, crabs most likely digest the bacteria attached to the surface of senescent leaves, providing an additional nitrogen source. For instance, the concentration of the amino sugar galactosamine in Rhizophora leaves increases during decomposition because of bacterial growth (Nordhaus et al. 2011).

In summary, these studies provide evidence that litter-consuming crabs assimilate nutrients from leaf litter despite the low protein content. However, our experiments showed that over time, the assimilated nitrogen obviously does not meet the crabs' requirements, resulting in the recycling of body nitrogen mirrored by a strong increase in tissue $\delta^{15} \mathrm{~N}$. In the field, Episesarma spp. supplement their mainly mangrove plant diet with small amounts of animal material (Nordhaus et al. 2011, C. M. Herbon pers. obs.), which is most likely necessary to fulfill the nitrogen needs over time.

Based on the assumption that crabs assimilate nitrogen from the leaves, there must be other reasons for the high $\Delta^{15} \mathrm{~N}$ in bulk tissues. The range of $\delta^{15} \mathrm{~N}$ is much greater for amino acids than for bulk tissues (Boecklen et al. 2011). Trophic amino acids, e.g. glutamic acid, alanine and leucine, are strongly fractionated relative to the diet in contrast to source amino acids, e.g. glycine, phenylalanine and histidine (e.g. McClelland \& Montoya 2002). Martínez del Rio \& Wolf (2005) reported that a nutritional deficiency of specific dietary nutrients may increase the feeding rate, causing additional metabolic cycling of nonessential nutrients, in this way increasing the $\Delta^{15} \mathrm{~N}$ values between animal tissue and diet. The high difference in fractionation regarding different amino
Table 5. Rhizophora mangle. Concentration of total hydrolyzable amino acids (THAA) and methionine of leaves that lay on the sediment surface for 3,5 and $7 \mathrm{~d}$ in the mangrove forest of the Segara Anakan Lagoon. Data are mean \pm SD ( $=3$ each). Data provided by T. Jennerjahn (pers. comm.). For details on the measurement see Nordhaus et al. (2011)

\begin{tabular}{|lcc|}
\hline Day & THAA $\left(\mu \mathrm{g} \mathrm{g}^{-1}\right)$ & Methionine $\left(\mu \mathrm{g} \mathrm{g}^{-1}\right)$ \\
\hline 3 & $15874.8 \pm 3610.7$ & $68.9 \pm 39.2$ \\
5 & $17806.6 \pm 1539.4$ & $111.5 \pm 6.4$ \\
7 & $15610.8 \pm 3108.7$ & $219.2 \pm 67.3$ \\
\hline
\end{tabular}

acids might have contributed to the high $\Delta^{15} \mathrm{~N}$ observed in our experiment.

According to Florin et al. (2011), low protein quality and high protein content have the potential to enhance $\Delta^{15} \mathrm{~N}$ by increasing the protein turnover. This is because as protein intake increases, nitrogen excretion will increase. The preferential retention of ${ }^{15} \mathrm{~N}$ leads to an elevation of $\Delta^{15} \mathrm{~N}$. The authors suggested a predictive equation considering protein quality $(X)$, defined as the methionine content as a percent of total dietary protein, and dietary protein content $(Z)$, given as a percent of total dietary dry matter: $\Delta^{15} \mathrm{~N}=7.62-2.11 X+0.015 Z$ (Florin et al. 2011). Protein quality and quantity accounted for $81 \%$ of the variation in $\Delta^{15} \mathrm{~N}$. Based on the amount of total hydrolyzable amino acids (THAA) as an approximation for the protein content and on the methionine content in senescent Rhizophora mangle leaves (Table 5; see Nordhaus et al. 2011 for details on the measurement of amino acids) that lay on the sediment surface for 5 and $7 \mathrm{~d}$, the predictive values for $\Delta^{15} \mathrm{~N}$ between crabs and leaves in the SAL amount to 6.3 and 4.7 , respectively. This is close to the observed $\Delta^{15} \mathrm{~N}$ after $70 \mathrm{~d}$ of the experiment which were between 5.0 and 5.7 considering both species and stations. The equation of Florin et al. (2011) is based on studies dealing with mammals and birds consuming plant matter and mixed diets of plants and animals; therefore, the validity of the equation for other taxonomic groups should be tested.

A high variation in $\delta^{15} \mathrm{~N}$ between the tissue of crustaceans and their food in relation to the protein content, amino acid composition or the $\mathrm{C}: \mathrm{N}$ ratio of the food has been reported in several studies (Dittel et al. 1997, Fantle et al. 1999, Waddington \& MacArthur 2008, Gamboa-Delgado \& Le Vay 2009). For juveniles of the white shrimp Litopenaeus vannamei, $\Delta^{15} \mathrm{~N}$ values were highest ( 7.7 to 7.8 ) when animals were fed on diets with a high amount of a soy protein isolate, which was ascribed to the comparatively lower availability of essential amino acids (i.e. lysine 
and methionine) in soy protein (Gamboa-Delgado \& Le Vay 2009). A high $\Delta^{15} \mathrm{~N}$ up to 6.6 was also recorded for postlarvae of Penaeus vannamei feeding on benthic macroalgae (Dittel et al. 1997). Experiments with locusts also demonstrated that animals feeding on a lower-quality diet (maize) had higher $\Delta \Delta^{15} \mathrm{~N}$ values $(5.1 \%$ in whole animals, $7.8 \%$ in muscle tissue) related to their diet than animals feeding on a higher-quality diet (wheat; $2.3 \%$ and $3.1 \%$, respectively, Webb et al. 1998).

Other factors could also have contributed to the relatively high fractionation factor recorded in our experiment, e.g. stress. Nitrogen is usually excreted mainly as urinary urea, in which $\delta^{15} \mathrm{~N}$ is significantly lower than that in the diet consumed (Ambrose 2000). The excretion of urinary urea can be increased by stress caused by laboratory conditions. This can increase the difference in $\delta^{15} \mathrm{~N}$ between a consumer's tissue and its food (Ambrose \& DeNiro 1986, Hobson 1993). Furthermore, it cannot be excluded that symbiotic bacteria or fungi in the digestive tract of the crabs are involved in assimilation. If the crabs in turn assimilate the symbionts, these microorganisms will contribute an additional trophic level in the digestive tract. This might result in an increased difference in $\delta^{15} \mathrm{~N}$ between crab tissue and leaves.

We recorded a high intra-species variation in tissue $\delta^{15} \mathrm{~N}$ and $\delta^{13} \mathrm{C}$ at both stations. This is in agreement with a study on Daphnia magna (Cladocera) which reported a high variability in organismic $\delta^{15} \mathrm{~N}$ when fed with green algae over $13 \mathrm{~d}$ (Adams \& Sterner 2000). In addition to a high intra-species variation, muscle $\delta^{15} \mathrm{~N}$ of Episesarma spp. differed temporally. Crabs used in this experiment and those used to examine tissue differences were collected at the same stations and in the same season but in different years. Their tissues had already significantly different $\delta^{15} \mathrm{~N}$ values ( $t$-tests: $\mathrm{p}<0.001$ for $E$. versicolor and $\mathrm{p}<0.01$ for $E$. singaporense), indicating a different food availability in the $2 \mathrm{yr}$.

The difference in $\delta^{13} \mathrm{C}$ between the leaves and muscle tissue of the crabs $\left(=\Delta^{13} \mathrm{C}\right)$ was similar at the beginning and at the end of the experiment (Table 2). $\delta^{13} \mathrm{C}$ in the crab tissues did not show an approximation to that of the mangrove leaves even after $90 \mathrm{~d}$. It is unlikely that $\delta^{13} \mathrm{C}$ would have changed after a longer period of time since the observed change in $\delta^{15} \mathrm{~N}$ showed that muscle tissue turnover time was lower. Therefore, a mainly leaf-based diet in the field prior to the experiment is likely, resulting in constant tissue $\delta^{13} \mathrm{C}$ values during the experiment. This is also in agreement with the $\delta^{15} \mathrm{~N}$ values which are in the range expected for a leaf-based diet (see above).
It seems clear that the discrimination factors for Episesarma spp. fed on a $R$. apiculata diet are much higher than the reported average values (e.g. Vander Zanden \& Rasmussen 2001, Caut et al. 2009). Several studies demonstrated that major biochemical components (lipids, proteins, carbohydrates) differ in $\delta^{13} \mathrm{C}$ signatures and that consumers assimilate components with varying efficiencies (e.g. DeNiro \& Epstein 1978, Focken \& Becker 1998). This contributes to the different carbon isotopic fractionation factors in carnivorous and herbivorous animals. A main reason for the high $\Delta^{13} \mathrm{C}$ in Episesarma spp. is probably a selective assimilation of amino acids with a high $\delta^{13} \mathrm{C}$ value. Feeding experiments with Callinectes sapidus demonstrated that essential amino acids in crabs were only slightly enriched in ${ }^{13} \mathrm{C}$ compared to their diet, whereas non-essential amino acids were significantly enriched in ${ }^{13} \mathrm{C}$, which was ascribed to different metabolic pathways (Fantle et al. 1999). Essential amino acids are directly derived from the diet, but non-essential amino acids, together with dietary lipids and carbohydrates, enter the tricarboxylic cycle, in which carbon is cycled prior to synthesis of amino acids, fatty acids or sugar (Fantle et al. 1999). As the concentrations of several essential amino acids in mangrove leaves are low, e.g. methionine (Table 5), high bulk $\Delta^{13} \mathrm{C}$ values between crabs and leaves are probably due to crabs selectively assimilating non-essential amino acids, which undergo many reactions involving isotope fractionation of carbon. In addition, variation in $\delta^{13} \mathrm{C}$ among amino acids is high (e.g. Fantle et al. 1999); thus, a selective assimilation of amino acids with a high $\delta^{13} \mathrm{C}$ value can contribute to a high discrepancy between $\delta^{13} \mathrm{C}$ in muscle tissue and bulk $\delta^{13} \mathrm{C}$ in the leaves.

Stable isotope analysis of individual carbohydrates also demonstrated that $\delta^{13} \mathrm{C}$ can vary between different sugars, e.g. $\delta^{13} \mathrm{C}$ in the plant Sphagnum sp. was between $-29.0 \%$ for rhamnose and $-26.1 \%$ for glucose. Also, the $\delta^{13} \mathrm{C}$ in cellulose was higher than bulk $\delta^{13} \mathrm{C}$ (Macko et al. 1991). The selective assimilation of specific carbohydrates can thus also contribute to an unexpectedly high difference in $\delta^{13} \mathrm{C}$ between diet and consumer.

A deviation from an average $\Delta^{13} \mathrm{C}$ of $0.8 \%$ (Peterson \& Fry 1987) was previously reported for different consumers and diets (McCutchan et al. 2003). Our results are in line with previous studies demonstrating high $\Delta^{13} \mathrm{C}$ values, e.g. they ranged between 3.8 and $4.7 \%$ for 2 salt marsh snails feeding on litter for 1 mo (Kurata et al. 2001). For postlarvae of Penaeus vannamei fed with detritus and meiofauna from a tropical mangrove, $\Delta{ }^{13} \mathrm{C}$ was at least $7 \%$ (Dittel et al. 1997). 
Also, other studies reported comparatively high $\Delta^{13} \mathrm{C}$ values, e.g. for lobsters Panulirus cygnus $\left(\Delta^{13} \mathrm{C}: 2.9\right.$ to 3.6) (Waddington \& MacArthur 2008). $\Delta^{13} \mathrm{C}$ therefore seems to strongly depend on the taxonomic group, feeding habit, food availability, protein quality and amino acid composition (Caut et al. 2009, Robbins et al. 2010, Boecklen et al. 2011, Florin et al. 2011). However, in most studies, the reasons for these comparatively high $\Delta^{13} \mathrm{C}$ values have remained unresolved.

For Episesarma spp., we conclude the following: discrepancies between crab muscle tissue and brown Rhizophora apiculata are comparably high (average $\Delta \Delta^{13} \mathrm{C}$ for all species and stations: $4.9 \%$ ) and are most likely due to the selective assimilation of isotopic heavy carbon compounds such as specific amino acids, sugars or cellulose. It is unlikely that the time frame of $3 \mathrm{mo}$ is insufficient to trace an approximation of $\delta^{13} \mathrm{C}$ in the crabs' long-term storage tissue (muscle) to those of the leaves. We assume that the crabs assimilated carbon during the experiment due to (1) the high consumption rates during the experiment, (2) the high contribution of leaves to their diet in the field, (3) the occurrence of molting during the experiment, and (4) the results of previous studies demonstrating that leaf-eating crabs assimilate nitrogen and carbon from Rhizophora leaves (e.g. Linton \& Greenaway 2007, Nordhaus \& Wolff 2007).

\section{Consumption rates}

Besides Rhizophora apiculata, the genus Episesarma preferentially consumed the shrub species Derris trifoliata followed by Avicennia alba. Perisesarma darwinense consumed $D$. trifoliata solely. This is in agreement with Nordhaus et al. (2011), who found that $46 \%$ of investigated stomachs of Episesarma spp. and Perisesarma spp. contained leaves of Rhizophora spp., $28 \%$ contained leaves of $D$. trifoliata and $26 \%$ contained leaves of Avicennia spp. By contrast, leaves of Aegiceras corniculatum were rarely recorded ( $4 \%$ of stomachs), which is in line with the low consumption rates determined in our study.

There was no correlation between $\% \mathrm{~N}, \% \mathrm{C}, \mathrm{C} / \mathrm{N}$ ratio, $\delta^{15} \mathrm{~N}$ or $\delta^{13} \mathrm{C}$ of the different leaves and the respective consumption rates in either crab species. Therefore, no influence of these leaf characteristics on leaf preferences can be deduced. This is in agreement with previous studies (Emmerson \& McGwynne 1992, Nordhaus \& Wolff 2007). Nordhaus et al. (2011) found that the food choice of Episesarma singaporense and Perisesarma spp. was not related to the $\mathrm{C} / \mathrm{N}$ ratio or total available nitrogen of mangrove leaves. They proved that, in particular, the nitrogen compound composition and hexosamines have an influence on food choices of these crabs. $R$. apiculata had the highest reactivity index, indicating a higher freshness and probably higher bioavailability of the nitrogenous organic matter, of all the leaves in their experiment (Nordhaus et al. 2011). As we used only brown leaves for our experiments, this could be an explanation for the high preference for $R$. apiculata. To our knowledge, no studies on amino acids and hexosamines of Derris trifoliata leaves are available. Therefore, we can only assume that similar reasons account for the preference for this species in the SAL.

Previous studies also found tannins, which are passive defense compounds of plants against herbivores, to be of importance for the food choice of mangrove crabs (Giddins et al. 1986, Steinke et al. 1993). However, other studies reported the opposite (Emmerson \& McGwynne 1992, Nordhaus \& Wolff 2007). Although Rhizophora spp. leaves have much higher concentrations of tannins than other mangrove species, e.g. Avicennia spp. (Kathiresan 2003, Rajendran \& Kathiresan 2007), the crabs in our experiments preferred the former, which indicates that tannins are of minor importance in food choice.

The preference for Derris leaves allows us to draw an important ecological conclusion. Logged mangrove areas in the SAL, which were then overgrown by Derris, still provide an important food source for Episesarma spp., as highest densities of Episesarma spp. were recorded directly among the Derris stands (Geist et al. 2012). Under these circumstances, deforestation of Rhizophora apiculata might not have an effect on leaf-feeders as previously assumed, presuming that other crab species would also consume Derris willingly. However, to confirm this reasoning, assimilation and growth rates of crabs feeding on Derris and Rhizophora leaves should be compared.

Thongtham \& Kristensen (2005) reported a consumption rate of Episesarma versicolor for Rhizophora apiculata leaves of $510 \mathrm{mg}$ leaf dry wt $\mathrm{crab}^{-1} \mathrm{~d}^{-1}$ in Phuket, Thailand. Salewski (2007) determined consumption rates of $E$. versicolor for $R$. apiculata of $15 \mathrm{mg}$ leaf dry wt $\mathrm{g}^{-1}$ crab wet wt $\mathrm{d}^{-1}$ in the SAL, which is less than $10 \%$ of the consumption rates found in this study. Factors that could have had an effect on the consumption rates in this study are (1) the previous starvation period of $4 \mathrm{~d}$ before each experiment, (2) the calculation of the consumption rate including correction coefficients for leaves, (3) stress induced by laboratory conditions, and possibly (4) the previous diet given in the experiments. The order in which the mangrove species were offered could have 
had an effect, as the crabs' digestion systems might adapt to the quality of the food offered. Also, a longer experimental period could have resulted in different average consumption rates. However, the significant decrease in the consumption rate after the change from Rhizophora to Acanthus leaves and its subsequently significant increase after the change from Acanthus to Derris leaves indicate that the order of the provided leaves most likely did not have an influence on the consumption rate.

In the case of $\Delta^{15} \mathrm{~N}$ (discrepancy between leaves and feces), significantly higher values were recorded for crabs feeding on leaves of Aegiceras corniculatum (Fig. 4). This indicates that from this mangrove species, more heavy nitrogen $\left({ }^{15} \mathrm{~N}\right)$ was taken up by the crabs compared to the other leaves offered. As A. corniculatum was also the species with the lowest consumption rates, it can be assumed that although it is not a preferred food source, crabs assimilate nitrogen from these leaves and selectively take up ${ }^{15} \mathrm{~N}$ nitrogen when food choice is limited.

In general, $\Delta^{15} \mathrm{~N}$ values between consumed mangrove leaves and the corresponding feces have high standard deviations. For several crabs, $\Delta^{15} \mathrm{~N}$ was high, indicating that a considerable fractionation occurred. By contrast, $\Delta^{15} \mathrm{~N}$ was small for other crabs. This could be partly explained by feeding under laboratory conditions, leading to stress. A mechanically incomplete breakdown of leaves and short time in the gut can lead to low assimilation efficiencies, visible in similar $\delta^{15} \mathrm{~N}$ values of feces and ingested leaves (Greenaway \& Linton 1995). It can be assumed that this was the case with several crabs in our experiment. As the final weight of excreted feces was not measured, we cannot make a statement about the actual assimilation rate of nitrogen. Thongtham \& Kristensen (2005) calculated an assimilation efficiency of $41 \%$ for carbon and nitrogen for Episesarma versicolor when fed on brown Rhizophora apiculata leaves.

\section{Comparison of tissues}

In Episesarma versicolor and Scylla serrata, significantly higher $\delta^{15} \mathrm{~N}$ values were found in the muscle tissue compared to hepatopancreas tissue. In addition, $\delta^{13} \mathrm{C}$ was significantly higher in the muscle tissue compared to hepatopancreas tissue in most of the species. Muscle tissue is a long-term storage tissue. The heavy isotopic fraction is accumulated in this tissue and mirrors the diet over a long period, such as in crustaceans (e.g. Mysis mixta and Neomysis integer), where it mirrors the diet for 6 to $8 \mathrm{wk}$ (Gorokhova \& Hansson 1999). Previous studies showed that tissues with low lipid content, such as muscle tissue, have higher $\delta^{13} \mathrm{C}$ and/or $\delta^{15} \mathrm{~N}$ values because of lower tissue turnover rates (e.g. McCutchan et al. 2003, Cabanellas-Reboredo et al. 2009). In agreement with our results, significantly higher $\delta^{13} \mathrm{C}$ and $\delta^{15} \mathrm{~N}$ values were recorded in muscles than in the hepatopancreas of the spider crab Maja brachydactyla (Bodin et al. 2007).

In our study, these tissue differences were not recorded for all species, which can partly be explained by high standard deviations (e.g. in Epixanthus dentatus) and a low number of replicates $(\mathrm{n}=5)$. In the case of Perisesarma spp., the $\delta^{15} \mathrm{~N}$ values of hepatopancreas and muscle tissue are similar, which could be due to the digestion of a ${ }^{15} \mathrm{~N}$-enriched diet before crab collection. In Metaplax elegans, even higher $\delta^{15} \mathrm{~N}$ values were recorded in the hepatopancreas compared to the muscle tissue. As M. elegans is a detritus feeder, this is probably due to a generally ${ }^{15} \mathrm{~N}$-depleted diet. The $\delta^{13} \mathrm{C}$ values of Uca forcipata suggest a mainly microalgae-based diet, which has been reported in previous studies (Rodelli et al. 1984, Meziane et al. 2002, Guest et al. 2004).

\section{Comparison of ovigerous and non-ovigerous females}

There are 2 possible explanations for similar $\delta^{15} \mathrm{~N}$ and $\delta^{13} \mathrm{C}$ values in ovigerous and non-ovigerous females. (1) The egg incubation time is shorter than the muscle tissue turnover time, and therefore possible differences in metabolism were not yet reflected in isotopic composition. Diele (2000) showed that egg incubation in the litter-consuming mangrove crab Ucides cordatus is 24 to $27 \mathrm{~d}$. In Sesarmidae, the egg incubation time is about 30 to $35 \mathrm{~d}$ (Flores \& Paula 2002). (2) The ovigerous crabs balance the discharge of light nitrogen $\left({ }^{14} \mathrm{~N}\right)$ to their eggs, e.g. by selective uptake of specific food items. In future studies, several tissues should be examined when comparing ovigerous and non-ovigerous females, and eggs in different stadia of development should be analyzed.

\section{Summary and conclusions}

The fractionation of $\delta^{13} \mathrm{C}$ and $\delta^{15} \mathrm{~N}$ between mangrove leaves and Episesarma singaporense and E. versicolor (Sesarmidae) was experimentally examined over 90 d. $\Delta^{15} \mathrm{~N}$ between Rhizophora apiculata 
leaves and muscle tissue was 5.0\% and 5.4\% for $E$. singaporense and E. versicolor, respectively, after 70 d. $\delta^{15} \mathrm{~N}$ in the muscle tissue increased significantly thereafter, most likely due to the internal recycling of nitrogen. By contrast, $\delta^{13} \mathrm{C}$ did not change and $\Delta^{13} \mathrm{C}$ was $5.1 \%$ and $4.1 \%$, respectively, after $90 \mathrm{~d}$.

The results most likely indicate that (1) crabs selectively assimilate isotopic heavy carbon compounds, such as specific amino acids, sugars or cellulose and (2) the low protein quality of mangrove leaves is probably responsible for the high $\Delta^{15} \mathrm{~N}$, which causes the selective assimilation of amino acids and additional metabolic cycling of non-essential nutrients.

The results show that bulk $\delta^{13} \mathrm{C}$ is not an appropriate tracer for the food sources of these mangrove crabs. The commonly accepted average difference between a consumer and its diet of 0 to $0.8 \%$ for bulk $\delta^{13} \mathrm{C}$ and 2.3 to $3.4 \%$ for bulk $\delta^{15} \mathrm{~N}$ is probably also inapplicable for other crustaceans which are herbivorous or facultative litter feeders. Instead, compoundspecific isotope analysis, including that of specific amino acids, should be conducted in further studies.

We conclude that Episesarma can meet their nitrogen demand over at least $50 \mathrm{~d}$ on a mangrove leaf diet. Leaves of Derris trifoliata and Rhizophora apiculata were preferentially consumed during experiments, indicating their higher nutritional value and probably better digestibility. Deforested areas, subsequently overgrown by $D$. trifoliata, therefore still provide a valuable food source for Episesarma spp.

Muscle tissue of Episesarma versicolor, Scylla serrata and Metaplax elegans had higher ${ }^{15} \mathrm{~N}$ and/or ${ }^{13} \mathrm{C}$ values compared to the hepatopancreas tissue, which is most likely due to lower turnover rates in muscle tissue. Isotopic compositions in tissues of ovigerous and non-ovigerous females were similar. Their egg incubation times are probably shorter than the muscle tissue turnover times.

Acknowledgements. The authors acknowledge the financial support from the German Federal Ministry of Education and Research (BMBF, Grant No. 03F0471A). Special thanks to A. Siph, S. Tiono, E. Hermawan, D. E. Maharatih, J. Permadi, D. Sukmarani, A. Suncoko and other students from Universitas Jenderal Soedirman (UNSOED), Purwokerto, Indonesia, for help during field work. Thanks to D. Pargmann, A. Ostmann and D. Dasbach for laboratory work and support. Thanks also to S. Bouillon for support and advice during the analysis and interpretation phase. Helpful comments of referees are thankfully acknowledged. This work was supported by the Bremen International Graduate School for Marine Sciences (GLOMAR), funded by the German Research Foundation (DFG) within the framework of the Excellence Initiative of the German federal and state governments to promote science and research at German universities.

\section{LITERATURE CITED}

Adams TS, Sterner RW (2000) The effect of dietary nitrogen content on trophic level ${ }^{15} \mathrm{~N}$ enrichment. Limnol Oceanogr 45:601-607

Ambrose SH (1991) Effects of diet, climate and physiology on nitrogen isotope ratios in terrestrial foodwebs. J Archaeol Sci 18:293-317

Ambrose SH (2000) Controlled diet and climate experiments on nitrogen isotope ratios of rats. In: Ambrose $\mathrm{SH}$, Katzenberg MA (eds) Biochemical approaches to paleodietary analysis. Kluwer Academic/Plenum Publishers, New York, NY, p 243-259

Ambrose SH, DeNiro MJ (1986) The isotopic ecology of East African mammals. Oecologia 69:395-406

Ardli ER (2007) Spatial and temporal dynamics of mangrove conversion at the Segara Anakan Cilacap, Java, Indonesia. In: Yuwono E, Jennerjahn TC, Sastranegara MH, Sukardi P (eds) Synopsis of ecological and socio-economic aspects of tropical coastal ecosystem with special reference to Segara Anakan. University of Jenderal Soedirman, Purwokerto, p 11-20

Ardli ER, Wolff M (2009) Land use and land cover change affecting habitat distribution in the Segara Anakan lagoon, Java, Indonesia. Reg Environ Change 9:235-243

Ashton EC (2002) Mangrove sesarmid crab feeding experiments in peninsular Malaysia. J Exp Mar Biol Ecol 273: 97-119

Bodin N, Le Loc'h F, Hily C (2007) Effect of lipid removal on carbon and nitrogen stable isotope ratios in crustacean tissues. J Exp Mar Biol Ecol 341:168-175

Boecklen WJ, Yarnes CT, Cook BA, James AC (2011) On the use of stable isotopes in trophic ecology. Annu Rev Ecol Evol Syst 42:411-440

Bouillon S, Moens T, Overmeer I, Koedam N, Dehairs F (2004) Resource utilization patterns of epifauna from mangrove forests with contrasting inputs of local versus imported organic matter. Mar Ecol Prog Ser 278:77-88

Buck TL, Breed GA, Pennings SC, Chase ME, Zimmer M, Carefoot TH (2003) Diet choice in an omnivorous saltmarsh crab: different food types, body size, and habitat complexity. J Exp Mar Biol Ecol 292:103-116

> Cabanellas-Reboredo M, Deudero S, Blanco A (2009) Stableisotope signatures $\left(\delta^{13} \mathrm{C}\right.$ and $\left.\delta^{15} \mathrm{~N}\right)$ of different tissues of Pinna nobilis Linnaeus, 1758 (Bivalvia): isotopic variations among tissues and between seasons. J Molluscan Stud 75: 343-349

> Caut S, Angulo E, Courchamp F (2009) Variation in discrimination factors $\left(\delta^{15} \mathrm{~N}\right.$ and $\left.\delta^{13} \mathrm{C}\right)$ : the effect of diet isotopic values and applications for diet reconstruction. J Appl Ecol 46:443-453

> Checkley DM, Miller CA (1989) Nitrogen isotope fractionation by oceanic zooplankton. Deep-Sea Res 36:1449-1456

Chen GC, Ye Y (2008) Leaf consumption by Sesarma plicata in a mangrove forest at Jiulongjiang Estuary, China. Mar Biol 154:997-1007

DeNiro MJ, Epstein S (1978) Influence of diet on the distribution of carbon isotopes in animals. Geochim Cosmochim Acta 42:495-506

$>$ DeNiro MJ, Epstein S (1981) Influence of diet on the distribution of nitrogen isotopes in animals. Geochim Cosmochim Acta 45:341-351

Diele K (2000) Life history and population structure of the exploited mangrove crab Ucides cordatus cordatus (Linnaeus, 1763) (Decapoda: Brachyura) in the Caete' Estu- 
ary, North Brazil. PhD thesis, University of Bremen

Dittel AI, Epifanio CE, Cifuentes LA, Kirchman DL (1997) Carbon and nitrogen sources for shrimp postlarvae fed natural diets from a tropical mangrove system. Estuar Coast Shelf Sci 45:629-637

Dittel AI, Epifanio CE, Schwalm SM, Fantle MS, Fogel ML (2000) Carbon and nitrogen sources for juvenile blue crabs Callinectes sapidus in coastal wetlands. Mar Ecol Prog Ser 194:103-112

Emmerson WD, McGwynne LE (1992) Feeding and assimilation of mangrove leaves by the crab Sesarma meinerti de Man in relation to leaf-litter production in Mgazana, a warm-temperate southern African mangrove swamp. J Exp Mar Biol Ecol 157:41-53

Fantle MS, Dittel AI, Schwalm SM, Epifanio CE, Fogel ML (1999) A food web analysis of the juvenile blue crab Callinectes sapidus, using stable isotopes in whole animals and individual amino acids. Oecologia 120:416-426

Flores AAV, Paula J (2002) Sexual maturity, larval release and reproductive output of two brachyuran crabs from a rocky intertidal area in central Portugal. Invertebr Reprod Dev 42:21-34

> Florin ST, Felicetti LA, Robbins CT (2011) The biological basis for understanding and predicting dietary-induced variation in nitrogen and sulphur isotope ratio discrimination. Funct Ecol 25:519-526

> Focken U, Becker K (1998) Metabolic fractionation of stable carbon isotopes: implications of different proximate compositions for studies of the aquatic food webs using $\delta^{13} \mathrm{C}$ data. Oecologia 115:337-343

Gamboa-Delgado J, Le Vay L (2009) Natural stable isotopes as indicators of the relative contribution of soy protein and fish meal to tissue growth in Pacific white shrimp (Litopeneus vannamei) fed compound diets. Aquaculture 291:115-123

> Gannes LZ, Martínez del Rio C, Koch P (1998) Natural abundance variations in stable isotopes and their potential uses in animal physiological ecology. Comp Biochem Physiol A 119:725-737

Geist SJ, Nordhaus I, Hinrichs S (2012) Occurrence of species-rich crab fauna in a human-impacted mangrove forest questions the application of community analysis as an environmental assessment tool. Estuar Coast Shelf Sci 96:69-80

Giddins RL, Lucas JS, Neilson MJ, Richards GN (1986) Feeding ecology of the mangrove crab Neosarmatium smithi (Crustacea: Decapoda: Sesarmidae). Mar Ecol Prog Ser 33:147-155

Gorokhova E, Hansson S (1999) An experimental study on variations in stable carbon and nitrogen isotope fractionation during growth of Mysis mixta and Neomysis integer. Can J Fish Aquat Sci 56:2203-2210

Greenaway P (1991) Nitrogenous excretion in aquatic and terrestrial crustaceans. Mem Queensl Mus 31:215-227

Greenaway P, Linton SM (1995) Dietary assimilation and food retention time in the herbivorous terrestrial crab Gecarcoidea natalis. Physiol Zool 68:1006-1028

> Guest MA, Connolly RM, Loneragan NR (2004) Carbon movement and assimilation by invertebrates in estuarine habitats at a scale of metres. Mar Ecol Prog Ser 278: $27-34$

Hagerman L (1983) Haemocyanin concentration of juvenile lobsters (Homarus gammarus) in relation to moulting cycle and feeding conditions. Mar Biol 77:11-17

Hinrichs S, Nordhaus I, Geist SJ (2009) Status, diversity and distribution patterns of mangrove vegetation in the Segara Anakan lagoon, Java, Indonesia. Reg Environ Change 9:275-289

Hobson KA (1993) Trophic relationships among high Arctic seabirds: insights from tissue-dependent stable isotope models. Mar Ecol Prog Ser 95:7-18

> Holtermann P, Burchard H, Jennerjahn T (2009) Hydrodynamics of the Segara Anakan lagoon. Reg Environ Change 9:245-258

Kathiresan K (2003) Insect foliovory in mangroves. Indian J Mar Sci 32:237-239

Klaassen M, Ens BJ (1993) Habitat selection and energetic of the fiddler crab (Uca tangeri). Neth J Sea Res 31:495-502

> Kristensen DK, Kristensen E, Mangion P (2010) Food partitioning of leaf-eating mangrove crabs (Sesarminae): experimental and stable isotope $\left({ }^{13} \mathrm{C}\right.$ and $\left.{ }^{15} \mathrm{~N}\right)$ evidence. Estuar Coast Shelf Sci 87:583-590

> Kurata K, Minami H, Kichuki E (2001) Stable isotope analysis of food sources for salt marsh snails. Mar Ecol Prog Ser 223:167-177

Kwok PW, Lee SY (1995) The growth performances of two mangrove crabs, Chiromanthes bidens and Parasesarma plicata, under different leaf litter diets. Hydrobiologia 295:141-148

> Linton SM, Greenaway P (1997) Urate deposits in the geocarcinid land crab Gecarcoidea natalis are synthesized de novo from excess dietary nitrogen. J Exp Biol 200: 2347-2354

> Linton SM, Greenaway P (2007) A review of feeding and nutrition of herbivorous land crabs: adaptations to low quality plant diets. J Comp Physiol B 177:269-286

Macko SA, Engel MH, Hartley G, Hatcher P, Helleur R, Jackman P, Silfer JA (1991) Isotopic compositions of individual carbohydrates as indicators of early diagenesis of organic matter in peat. Chem Geol 93:147-161

Martínez del Rio C, Wolf B (2005) Mass-balance models for animal isotopic ecology. In: Starck JM, Wang T (eds) Physiological and ecological adaptations to feeding in vertebrates. Science Publishers, Enfield, NH, p 141-174

Mazumder D, Saintilan N (2009) Mangrove leaves are not an important source of dietary carbon and nitrogen for crabs in temperate Australian mangroves. Wetlands 30:375-380

> McClelland JW, Montoya JP (2002) Trophic relationships and the nitrogen isotopic composition of amino acids in plankton. Ecology 83:2173-2180

McCutchan JH, Lewis WM, Kendall C, McGrath CC (2003) Variation in trophic shift for stable isotope ratios of carbon, nitrogen and sulfur. Oikos 102:378-390

Meziane T, Sanabe MC, Tsuchiya M (2002) Role of fiddler crabs of a subtropical intertidal flat on the fate of sedimentary fatty acids. J Exp Mar Biol Ecol 270:191-201

- Micheli F (1993) Feeding ecology of mangrove crabs in North Eastern Australia: mangrove litter consumption by Sesarma messa and Sesarma smithii. J Exp Mar Biol Ecol 171:165-186

> Minagawa M, Wada E (1984) Stepwise enrichment of ${ }^{15} \mathrm{~N}$ along food chains: further evidence and the relation between $\delta^{15} \mathrm{~N}$ and animal age. Geochim Cosmochim Acta 48:1135-1140

> Møller H, Lee SY, Paterson B, Mann D (2008) Cannibalism contributes significantly to the diet of cultured sand crabs, Portunus pelagicus (L.): a dual stable isotope study. J Exp Mar Biol Ecol 361:75-82

> Nordhaus I, Wolff M (2007) Feeding ecology of the mangrove crab Ucides cordatus (Ocypodidae): food choice, 
food quality and assimilation efficiency. Mar Biol 151: 1665-1681

Nordhaus I, Salewski T, Jennerjahn TC (2011) Food preferences of mangrove crabs related to leaf nitrogen compounds in the Segara Anakan Lagoon, Java, Indonesia. J Sea Res 65:414-426

O'Donnell MJ, Wright JC (1995) Nitrogen excretion in terrestrial crustaceans. In: Walsh PJ, Wright P (eds) Nitrogen metabolism and excretion. CRC Press, Boca Raton, FL, p 105-118

Peterson BJ, Fry B (1987) Stable isotopes in ecosystem studies. Annu Rev Ecol Syst 18:293-320

Post DM (2002) Using stable isotopes to estimate trophic position: models, methods, and assumptions. Ecology 83: 703-718

Rajendran N, Kathiresan K (2007) Microbial flora associated with submerged mangrove leaf litter in India. Rev Biol Trop 55:393-400

Robbins CT, Felicetti LA, Florin ST (2010) The impact of protein quality on stable nitrogen isotope ratio discrimination and assimilated diet estimation. Oecologia 162: 571-579

Rodelli MR, Gearing JN, Gearing PJ, Marshall N, Sasekumar A (1984) Stable isotope ratio as a tracer of mangrove carbon in Malaysian ecosystems. Oecologia 61:326-333

Salewski T (2007) Abbau der Blattstreu von Mangroven und Ernährungsökologie der dominanten Krabbenarten in der Segara Anakan Lagune, Java, Indonesien. Diploma thesis, University of Bremen

Sastranegara MH, Fermon H, Mühlenberg M (2003) Diversity and abundance of intertidal crabs at the east swampmanaged areas of Segara Anakan Cilacap, Central Java, Indonesia. Proc Deutscher Tropentag, Technological and institutional innovations for sustainable rural develop-

Editorial responsibility: Steven Morgan,

Bodega Bay, California, USA ment, October 8-10, 2003, Göttingen

Steinke TD, Rajih A, Holland AJ (1993) The feeding behaviour of the red mangrove crab Sesarma meinerti De Man, 1887 (Crustacea: Decapoda: Grapsidae) and its effect on the degradation on mangrove leaf litter. Afr J Mar Sci 13: $151-160$

> Thongtham N, Kristensen E (2005) Carbon and nitrogen balance of leaf-eating sesarmid crabs (Neoepisesarma versicolor) offered different food sources. Estuar Coast Shelf Sci 65:213-222

Vander Zanden MJ, Rasmussen JB (2001) Variation in $\delta^{15} \mathrm{~N}$ and $\delta^{13} \mathrm{C}$ trophic fractionation: implications for aquatic food web studies. Limnol Oceanogr 46:2061-2066

Waddington K, MacArthur L (2008) Diet quality and muscle tissue location influence consumer-diet discrimination in captive-reared rock lobsters (Palinurus cygnus). Mar Biol 154:569-576

> Webb SC, Hedges REM, Simpson SJ (1998) Diet quality influences the $\delta^{13} \mathrm{C}$ and $\delta^{15} \mathrm{~N}$ of locusts and their biochemical components. J Exp Biol 201:2903-2911

Wolcott DL, Wolcott TG (1984) Food quality and cannibalism in the red land crab, Gecarcinus lateralis. Physiol Zool 57:318-324

Wolcott DL, Wolcott TG (1987) Nitrogen limitation in the herbivorous land crab Cardisoma guanhumi. Physiol Zool 60:262-268

> Ya BP, Yeo D, Todd PA (2008) Feeding ecology of Perisesarma (Crustacea: Decapoda: Brachyura: Sesarmidae) in Mandai mangroves, Singapore. J Crustac Biol 28: 480-484

Yokoyama H, Tamaki A, Harada K, Shimoda K, Koyama K, Ishihi Y (2005) Variability of diet-tissue isotopic fractionation in estuarine macrobenthos. Mar Ecol Prog Ser 296: $115-128$

Submitted: May 21, 2012; Accepted: May 27, 2013 Proofs received from author(s): August 21, 2013 